\title{
Composition and volume of the rumen microbiota of sheep fed on grass silage with different sucrose, starch and cellulose supplements
}

\author{
LiIsa Syrjälä ${ }^{1}$ ), Hannu Saloniemi ${ }^{2}$ ) and Leena Laalahti ${ }^{1}$ ) \\ 1) Department of Animal Husbandry, University of Helsinki \\ $\left.{ }^{2}\right)$ Department of Animal Hygiene, College of Veterinary Medicine, Helsinki
}

\begin{abstract}
A comparative study was made of the effect of different sucrose, starch and cellulose supplements and the effect of different silage preservatives on the quality and quantity of the rumen microbiota of sheep fed on grass silage. The levels of the carbohydrate supplements were $15 \%$ and $30 \%$ of the dry matter of the daily rations, representing $21 / 2$ and $5 \mathrm{~g} / \mathrm{kg}$ animal live weight per day. The silages were prepared with three different preservatives: 1) AIV I solution (25\% formic acid and $20 \%$ hydrocloric acid), 2) formic acid and 3) Viher solution (26\% formic acid and $70 \%$ formalin).

The total number of ciliates was highest in the animals receiving sucrose with the silage, lower in those given starch and lowest in those given cellulose. On the pure silage diet, it was between those for the starch and cellulose diets. The total number of bacteria decreased in the opposite direction on the different diets.

The sucrose supplements increased the numbers of small ciliates especially and the cellulose supplements those of the bigger ciliates. The total volume of the ciliate fauna was thus highest in the animals on cellulose diets, lower in those on starch diets and lowest in those on sucrose diets.

The total microbe mass constituted the following percentages of the rumen content on the different diets: only silage $4.1,15 \%$ sucrose $3.5,30 \%$ sucrose $3.5,15 \%$ starch $4.0,30 \%$ starch $4.5,15 \%$ cellulose 4.6 and $30 \%$ cellulose 5.2 . Bacteria constituted $77-86 \%$ of the total microbe mass on the different diets, the precentage being highest on the sucrose diets and lowest on the cellulose diets.

Only small differences were found between the different silage preservatives in the effect on the rumen microbiota.
\end{abstract}

In the fermentation processes occurring during ensiling of grass, the sugars and other soluble carbohydrates disappear from the grass more or less completely, depending on the preservation methods used, producing organic acids and gases. At the same time the solubility of the nitrogenous components increases. As readily fermentable carbohydrates are important as an energy source for rumen microbes, their scarcity or absence might be expected to affect the quality and quantity of the rumen microbiota, and also the utilization of the feed, in animals on grass silage-based diets. However, little information is available on these questions. Another subject that needs study is the effect 
of the organic acids formed during silage fermentation and the $\mathrm{pH}$ of silage on the rumen microbes. Although the feeding value of lactic acid is almost as great as that of glucose (BARNETT 1954) and the value of volatile fatty acids is considerable, since they are absorbed both directly from the rumen and through the intestinal wall, these fermentation products are not an energy source for so large an amount of the rumen microbes as the soluble carbohydrates.

The use of different carbohydrate supplements with hay and similar forage has been investigated in many experiments (Mitchell and Hamiton 1940, Hamilton 1942, Barnett and Reid 1961, Komkris et al. 1965, Sutton 1968, Kellogg 1969, SYRJÄLÄ 1971, SALO et al. 1973 b), with widely varying results. Less attention has been paid to the effect of adding sugars or other readily available carbohydrates as an energy source for rumen microorganisms in silage diets. The digestibility coefficients of silage were found to decrease with increasing amounts of sucrose or starch supplements, whereas with cellulose supplements they tended to increase in some cases. Sucrose supplements seemed to promote the utilization of the nitrogenous components of silage better than starch or cellulose supplements at the same levels, animals on the sucrose diets showing a somewhat higher $\mathrm{N}$ balance and lower rumen $\mathrm{NH}_{3}-\mathrm{N}$ contents than those on the other diets (SYRJÄLÄ 1972). SALO et al. (1973 a) found that varying the amounts of sucrose and starch supplements had little or no effect on the digestibility of silage by sheep. The capacity of sucrose and starch supplements to increase the live-weight gain, silage intake and feed utilization of growing lambs seemed to depend on the fermentation level of the silage (SYRJÄLÄ 1975).

The purpose of this experiment is to examine the quantity and quality of the rumen microbiota of sheep on pure silage diets and the effect on the microbiota of different sucrose, starch and cellulose supplements. Attention will also be paid to the effect of different silage preservatives. This study is closely connected with the earlier investigation on carbohydrate supplements (SYRJÄLÄ 1972), because it provided the rumen samples for the present experiment.

\section{Experimental procedures}

\section{Experimental design and rations}

The experiment was performed with nine rumen-fistulated adult Finnsheep rams according to a Latin-square design. The design of the experiment, the composition of the rations and the feeding of the animals are explained in detail in the earlier study (SYRJÄLÄ 1972).

The silages were prepared with three different preservatives: AIV I $(25 \%$ formic acid and $20 \%$ hydrochloric acid), formic acid (86\%) and Viher solution (26\% formic acid and $70 \%$ formalin). The carbohydrate supplements given with the silages were pure sucrose, potato starch and sulphite cellulose from the wood industry. Each carbohydrate supplement was given at two levels, constituting $15 \%$ and $30 \%$ of the dry matter of the daily rations, which averaged $928 \mathrm{~g}$. The supplements thus represented about $2 \frac{1}{2} \mathrm{~g}$ and $5 \mathrm{~g}$ per $\mathrm{kg}$ animal live weight. Pure silage diets were also given. 


\section{Sampling}

The samples of rumen liquid were collected as described by SYRJÄLÄ (1972). Only the samples taken in the morning before feeding were used in this microbial work. Five millilitres of rumen liquid was transferred to a glass bottle containing $44 \mathrm{ml}$ of $4 \%$ formol ( $10 \%$ formalin). Before the counting, $1 \mathrm{ml}$ of methyl green ( $1 \mathrm{~g}$ methyl green and $2 \mathrm{ml}$ glacial acetic acid and $100 \mathrm{ml}$ aqua destillata) was added to each sample. In this way the original rumen sample was diluted to $1: 10$, and the nuclei of the ciliates were stained deep bluish green. The staining was completed within 30 minutes.

\section{Counting the ciliates}

The ciliate cells were counted and identified by a modification of the method of Westerling (1970 a). The modified Fuchs-Rosenthal chamber B. S. 748 Chawksley \& Sons Ltd, London), which is divided into 12 rows of 12 square fields, was used. The side of a square is $0.25 \mathrm{~mm}$ and the depth of the chamber is $0.2 \mathrm{~mm}$. The total capacity of the chamber is thus $1.8 \mathrm{~mm}^{3}$. Ten counts were performed on each rumen sample. In this way, the ciliates of $18 \mathrm{~mm}^{3}$ of diluted rumen contents were counted.

\section{Identification of the ciliates}

The species were identified on the basis of the descriptions and figures of Dogiel (1927), and Kofoid and MacLennan $(1930,1932,1933)$ and according to the taxonomy of DoGIEL, account also being taken of the principles of Noirot-Timothee (1960).

\section{Counting the bacteria}

The bacterial cells were counted as described by SYRJ $\mathrm{A} L \ddot{A}$ et al. (1973). Three preparations were made of each rumen sample for the counts.

\section{Determination of the volume of the fauna and flora}

The mean cell volume of each ciliate species was calculated according to the geometrical method introduced by Schumacher (1962).

The mean dimensions used and the cell volumes for each ciliate species are shown in Table 1. The cell volumes are rounded up to two digits on account of computer processing.

For the bacterial cells the mean volume of $1 \mu^{3}$ was used (WARNER 1962).

\section{Results and discussion}

\section{Effect of sucrose, starch and cellulose supplements}

The results are combined for all the silages and are the averages of 54 samples for the $0 \%$ carbohydrate diet and of 18 samples for each of the diets containing carbohydrate supplements. Altogether 162 samples were analysed. 
Table 1. Lengths (L), widths (W) and thicknesses (T) of ciliate cells $(\mu)$ and the cell volumes (VOL) $\left(\mu^{3} \times 10^{4}\right)$.

\begin{tabular}{|c|c|c|c|c|c|}
\hline & $\mathbf{L}$ & W & $\mathrm{T}$ & VOL & Reference \\
\hline Charon ................................. & 25 & 12 & 10 & 0.15 & 1 \\
\hline Entodinium vorax ............ & 95 & 68 & 60 & 20 & 2 \\
\hline 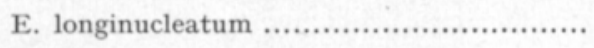 & 43 & 33 & 23 & 1.7 & 3 \\
\hline 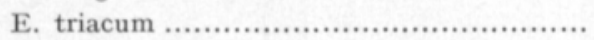 & 35 & 25 & 18 & 0.8 & 2 \\
\hline 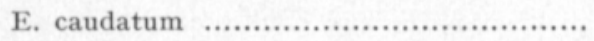 & 43 & 33 & 23 & 1.7 & 2 \\
\hline 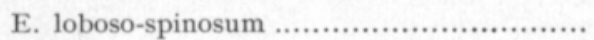 & 39 & 26 & 18 & 1.0 & 2 \\
\hline E. nanellum . ................................... & 28 & 15 & 11 & 0.25 & 3 \\
\hline 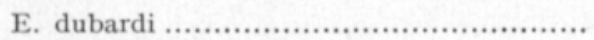 & 43 & 25 & 18 & 1.0 & 2 \\
\hline Diplodinium dentatum ......................... & 71 & 56 & 44 & 9 & 3 \\
\hline Eudiplodinium maggii ........................... & 140 & 91 & 83 & 55 & 3 \\
\hline 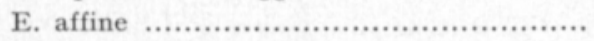 & 80 & 45 & 40 & 8 & 4 \\
\hline E. neglectum & 79 & 47 & 40 & 8 & 3 \\
\hline Polyplastron multivesiculatum .................... & 161 & 95 & 91 & 73 & 2 \\
\hline Enoploplastron triloricatum .................... & 90 & 50 & 35 & 8 & 5 \\
\hline
\end{tabular}

1. Our own measurements 2. Dogiel (1927). 3. Kofoid and MacLennan (1930, 1932, 1933). 4. Noirot-Timothee (1960). 5. Westerling (1970 b).

Number and kinds of ciliate and bacteria cells

Giliate species. The ciliates found in the rumen fluid of the experimental animals represented 14 different species (Table 2). Not all the species were found in every sample. For instance, Entodinium vorax and Eudiplodinium neglectum were found in only one third of the samples and Entodinium triacum, E. loboso-spinosum, Diplodinium dentatum and Eudiplodinium maggii in two thirds of the samples. Only Entodinium nanellum and E. dubardi were found in all the samples. Charon was the only representative of the holotrichs. It was found in large number and occurred in all the animals except one in one period.

On average, $\mathbf{5 0} \%$ of the total ciliates were holotrichs (Charon) and $\mathbf{5 0} \%$ entodiniomorphs, about $45 \%$ belonging to the genus Entodinium and $5 \%$ to the genus Diplodinium.

Descriptions of the ruminal fauna in the literature reveal large variations in the quality and quantity, depending on nutritional and many other factors (Hungate 1966). In domestic ruminants on normal feeding, the fauna sometimes comprises more than 30 different species and sometimes less than 10 . On some special diets, such as high urea diets, all the ciliates may be lacking (Virtanen 1967).

Charon has been found to occur only occasionally in the rumen (Hungate 1966), whereas the holotrichs Isotricha prostoma, I. intestinalis and Dasytricha ruminantium occur frequently. However, these Isotricha and Dasytricha holotrichs were completely lacking in the animals in this experiment. Holotrichs require soluble sugars as a source of energy (HUNGATE 1966). For this reason they are present in especially large number in grazing ruminants and those on a diet containing a considerable fraction of good quality hay. Their absence from the animals on the pure silage diet is thus understandable, as its sugar 


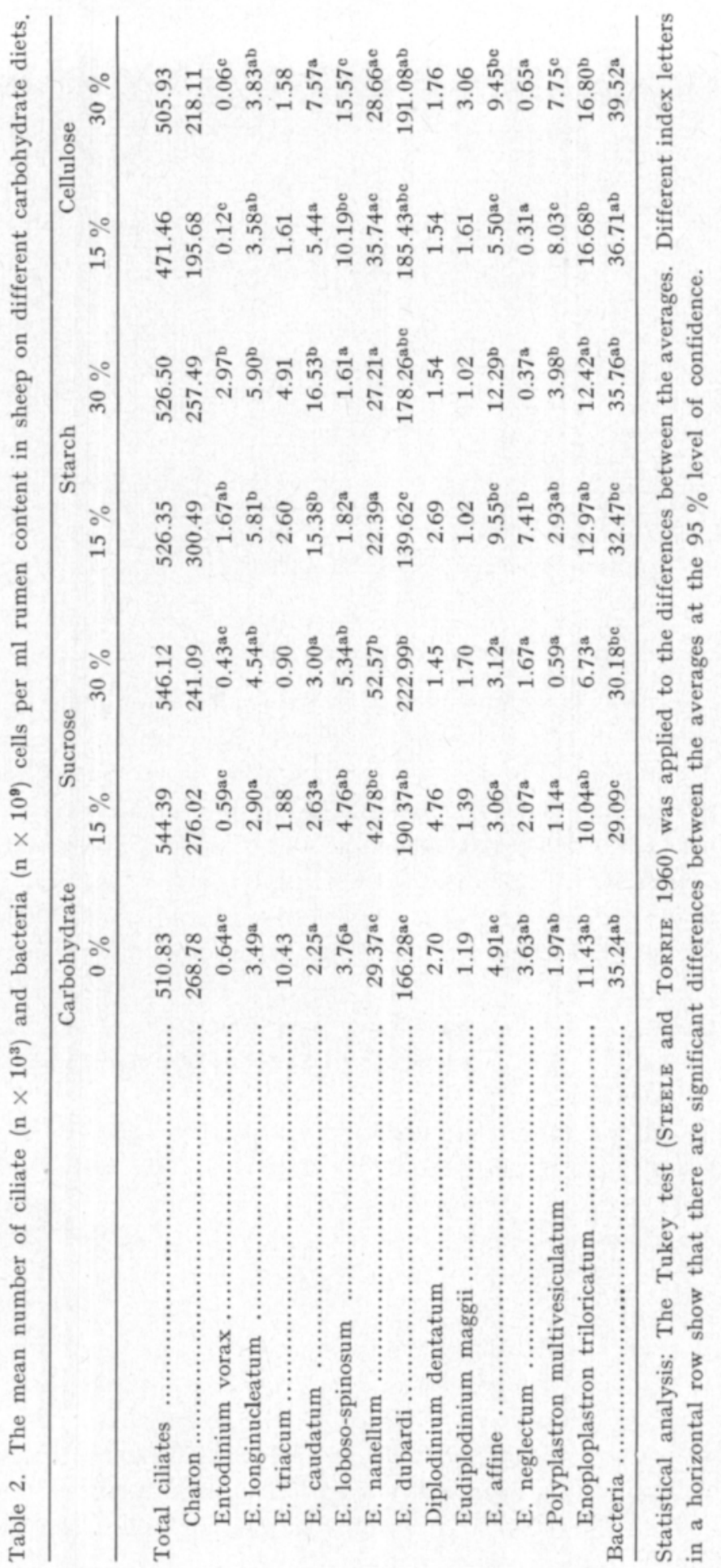


content was rather low (SYRJÄLÄ 1972). But it is more difficult to explain why they did not occur when the sucrose supplements were given. One reason may be that before the experiment began the animals were kept for a long time on silage alone, during which period these ciliates probably disappeared. Moreover, during the experiment they were separated from other ruminants and there was no possibility of contamination.

Total numbers of cells. Some differences were found between the total numbers of ciliates in the animals on different carbohydrate diets, but these were not significant $(\mathrm{P}>0.05)$. The sucrose and starch supplements increased the total numbers of rumen ciliates and cellulose supplements decreased them, as compared with the pure silage diet (Table 2, Fig. 1). If the number of ciliates on the pure silage diet is taken as 100 , the relative values are 107 for the $15 \%$ and $30 \%$ sucrose diets, 103 for both the starch diets, and 92 and 99 for the cellulosa diets.

The numbers of bacteria were lower on the sucrose $(\mathrm{P}<0.05)$ and starch diets than on the cellulose diets. When the number of bacteria on the pure silage diet is taken as 100 , the relative values are 83 and 86 on the $15 \%$ and $30 \%$ sucrose diets, respectively, 92 and 101 on the starch diets and 104 and 112 on the cellulose diets.

The finding that the sucrose and starch supplements tended to increase the quantity of ciliate cells and decrease that of the bacteria cells, and that cellulose had the opposite effect can be at least partly explained by the different solubility of these carbohydrates. The rumen ciliates ingest sugars and starch very rapidly and thus remove them from bacterial attack (Hungate 1966). Cellulose is ingested more slowly, so that the bacteria are probably better able to compete for it. Besides being superior in the competition for food, protozoa can also use bacteria as their food, which explains the decreased bacterial population in faunated sheep as compared to defaunated (EADIE and HoBson 1962).

The $\mathrm{pH}$ of the rumen fluid on the carbohydrate diets was somewhat lower than on the pure silage diets. Even when fermentation was strongest, however, it kept within the limits of 6.1 and 6.9 (SYRJ $\ddot{L} L \ddot{A}$ 1972). This range is optimal for ciliates, which are rather sensitive to acidity (PURSER and MoIR 1959). Entodinium species are somewhat more resistant to acid than are the holotrichs (Aвоч AккаDA et al. 1959), but all the ciliates die rapidly at very high rumen acidities (Hungate et al. 1952). The $\mathrm{pH}$ range outside which they do not survive has been found to be 5.5-8.0 (KROGH 1959, Quinn et al. 1962). According to Hungate (1955), ciliates die at $\mathrm{pH} 4.5$.

Some variations in the numbers of the different ciliate species were found between the diets having different carbohydrate sources. The cellulose supplements decreased the numbers of Charon, compared with the pure silage diet, whereas the sucrose and starch supplements had little effect on them $(\mathrm{P}>$ 0.05). The total numbers of entodinia were highest on the sucrose diets and lowest on the starch diets, especially the $15 \%$ starch diets. However, not all the entodinia species were affected in this way by the starch supplements; on the contrary, only Entodinium loboso-spinosum, E. nanellum and E. dubardi were decreased and the numbers of the other entodinia, especially E. vorax, E. longinucleatum and E. caudatum, were higher on the starch than on the other diets, sometimes significantly so $(\mathrm{P}<0.05)$. 
The total numbers of diplodinia decreased with the sucrose supplements, especially the $30 \%$ supplement, but increased with the starch and cellulose supplements. On the $30 \%$ cellulose diet the number was 2.6 times as high as on the $30 \%$ sucrose diet.

In grass silage-based diets, the effect of the different carbohydrate supplements on the ruminal fauna can be explained by the nutritional requirements of the different genera (Hungate 1966). All the entodiniomorphs, except some small species of Entodinium, utilize starch, whereas holotrichs assimilate soluble sugars. Entodiniomorphs are thus usually abundant in the rumen of animals given a high-concentrate ration and holotrichs appear in greatest quantity in animals given hay or other forages rich in soluble sugars (WARNER 1965, ABE et al. 1973). The cultural, enzymatic, and microscopic evidence suggests that cellulose is also digested by many entodiniomorphs (Hungate 1966). OXFord (1955) showed that rumen ciliates are capable of digesting both starch and cellulose and may utilize a number of soluble carbohydrates.

The differences in the numbers of the various ciliate species between the different levels of the same carbohydrate source were not significant $(\mathrm{P}>$ 0.05), except in the case of Eudiplodinium neglectum, which was more numerous $(\mathrm{P}<0.01)$ on the $15 \%$ starch than on the $30 \%$ starch diet. This shows that neither the level of the carbohydrate nor the level of the protein in the diet had any clear effect on the rumen microbiota in this experiment. As the silage was the only suurce of protein in the diet, the protein content decreased when the carbohydrate supplement increased. The crude protein content averaged $18.7 \%$ of dry matter in the pure silage diet, $15.9 \%$ in the $15 \%$ carbohydrate diets and $13.1 \%$ in the $30 \%$ carbohydrate diets (SYRJÄL $\ddot{A}$ 1972). However, even at the lowest levels in this experiment, the protein content was too high to inhibit the growth of the rumen microbes. In experiments where a high positive correlation has been found between the level of protein in the diet and the total amount of microorganisms in the rumen, the protein content of the diet has been lower, the maximum being $12 \%$ of dry matter (Molr and Williams 1950).

Percentage composition of the fauna. The carbohydrate supplements caused some changes in the composition of the ciliate fauna as compared with that of the pure silage diet (Fig. 3). The representation of the genera and subgenera in the total fauna generally varied less than that of the single species.

Charon constituted more than half of the total ciliate numbers on the pure silage diet and on the $15 \%$ sucrose and starch diets. The lowest percentages for Charon were obtained on the cellulose diets. Its representation on the cellulose diets was about $10 \%$ units lower than on the pure silage diet. The proportion of the genus Entodinium was lowest on the $15 \%$ starch diet, being sligtly more than one third of the total number of the fauna, and highest on the $30 \%$ sucrose diet and both cellulose diets, where it constituted about half of the fauna. The genus Diplodinium composed $3-8 \%$ of the fauna on the different diets, its contribution being lowest on the sucrose and highest on the cellulose diets. 


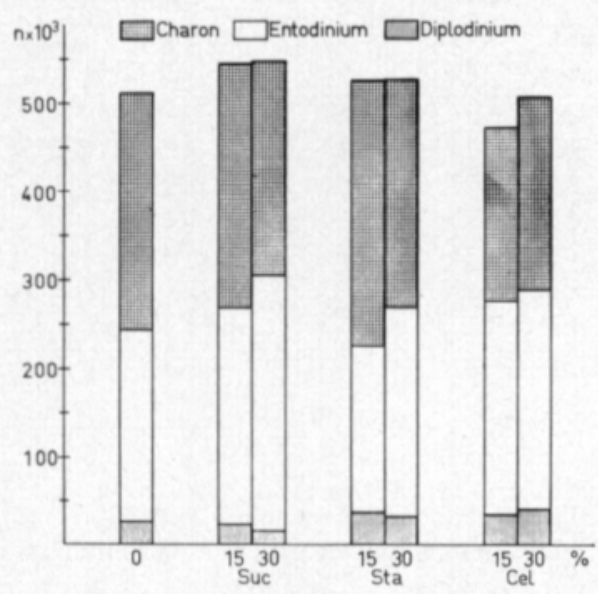

Fig. 1. The mean number of ciliate cells $\left(\mathrm{n} \times 10^{3}\right)$ per $\mathrm{ml}$ rumen content in sheep on different carbohydrate diets $(\mathrm{O}=$ only silage, $\mathrm{Suc}=$ sucrose, $\mathrm{Sta}=\mathrm{starch}, \mathrm{Cel}=$ cellulose $)$.

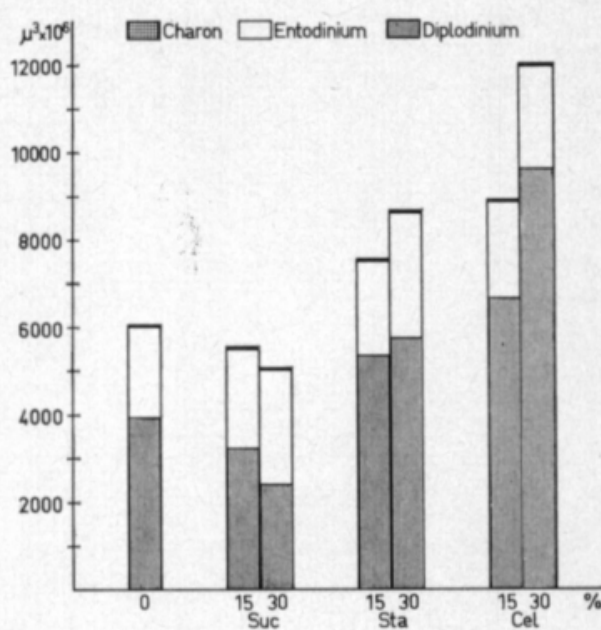

Fig. 2. The mean volume of ciliates $\left(\mu^{3} \times 10^{6}\right)$ per $\mathrm{ml}$ rumen content in sheep on different carbohydrate diets $(\mathrm{O}=$ only silage, Suc $=$ sucross, $\mathrm{Sta}=$ starch, $\mathrm{Cel}=$ cellulose $)$.

Volume of the microbe mass

Significant differences $(\mathrm{P}<0.05)$ were found in the total volume of the ciliates between the different diets. The total volumes were highest on the cellulose diets, somewhat lower on the starch diets and lowest on the sucrose and pure silage diets (Table 3, Fig. 2). The changes in total volume thus went in the opposite direction to those in the total numbers of ciliate cells, which decreased from the sucrose diets to the starch diets to the cellulose diets. This is due to the size of the ciliates cells affected by the carbohydrate supplements. Cellulose increased the numbers of the bigger entodiniomorphs especially, whereas sucrose raised the numbers of the small holotrichs. The large ciliate volumes on the cellulose and starch diets, as compared with the sucrose diets, are attributable in particular to the massive Polyplastron (Fig. 4).

Table 3. The mean volume of ciliates $\left(\mu^{3} \times 10^{6}\right)$ per ml rumen content in sheep on different carbohydrate diets and the distribution by genera or subgenera.

\begin{tabular}{|c|c|c|c|c|c|c|c|}
\hline \multirow{2}{*}{\multicolumn{2}{|c|}{$\begin{array}{cc}\text { Carbohydrate } \\
0 \% \\
\end{array}$}} & \multicolumn{2}{|c|}{ Sucrose } & \multicolumn{2}{|c|}{ Starch } & \multicolumn{2}{|c|}{ Cellulose } \\
\hline & & $15 \%$ & $30 \%$ & $15 \%$ & $30 \%$ & $15 \%$ & $30 \%$ \\
\hline otal ciliates & . $6049^{\mathrm{e}}$ & $5547^{\circ}$ & $5080^{e}$ & $7541^{\text {be }}$ & $8676^{\mathrm{b}}$ & $8914^{\mathrm{ab}}$ & $12042^{\mathrm{a}}$ \\
\hline Charon ........... & $21^{\mathrm{ae}}$ & $22^{\mathrm{ae}}$ & $6^{\mathrm{b}}$ & $17^{\mathrm{ab}}$ & $20^{\mathrm{abc}}$ & $20^{\text {abe }}$ & $33^{\mathrm{e}}$ \\
\hline Entodinium ........... & . $2085^{\mathrm{a}}$ & $2285^{\text {abe }}$ & $2637 \mathrm{be}$ & $2185^{\mathrm{ab}}$ & $2880^{\mathrm{e}}$ & $2235^{\text {abe }}$ & $2357^{\mathrm{ab}}$ \\
\hline Diplodinium .......... & . 3943ad & $3240^{\text {ad }}$ & $2437^{\mathrm{a}}$ & $5339^{a b d}$ & $5776^{\text {bd }}$ & $6659^{b}$ & $9652^{\mathrm{e}}$ \\
\hline Diplodinium .... & . 243 & 428 & 131 & 242 & 139 & 139 & 158 \\
\hline Eudiplodinium . & . 1340 & 1175 & 1317 & 1917 & 1752 & 1348 & 2490 \\
\hline Polyplastron ..... & $1436^{\mathrm{a}}$ & $834^{a}$ & $428^{a}$ & $2142^{\mathrm{ab}}$ & $2909^{\mathrm{ab}}$ & $3838^{\text {be }}$ & $5660^{e}$ \\
\hline Enoploplastron . & . $924^{\text {abe }}$ & $803^{a c}$ & $561^{\mathrm{a}}$ & $1038^{\mathrm{abe}}$ & $976^{\text {abe }}$ & $1334^{\mathrm{bc}}$ & $1344^{b}$ \\
\hline
\end{tabular}

Meaning of index letters same as in Table 2. 


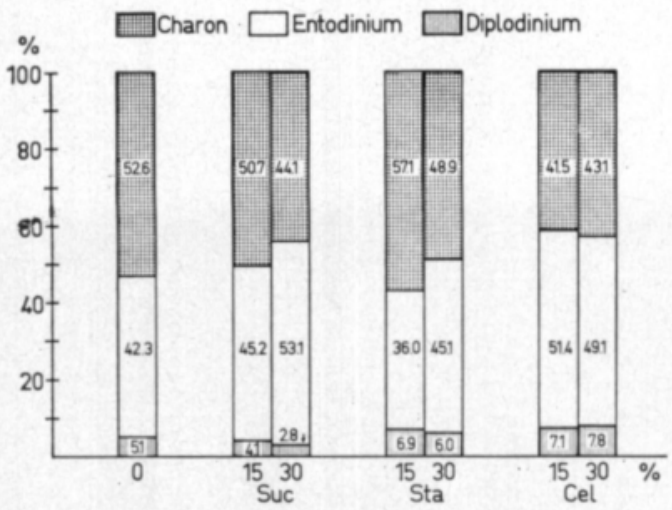

Fig. 3. The percentage composition of ciliate cells on the different carbohydrate diets.

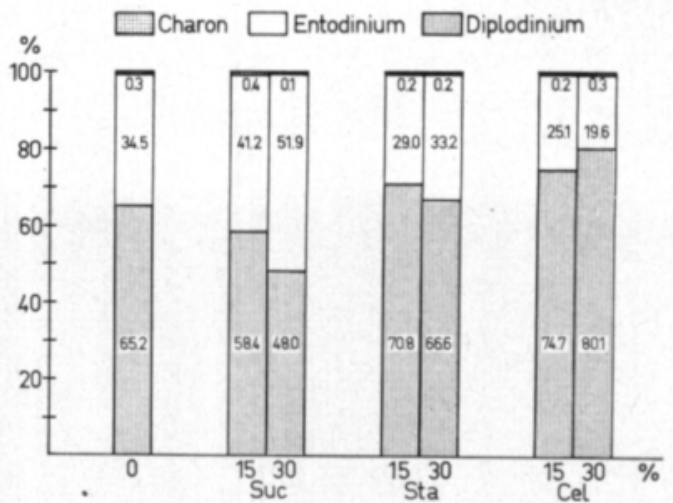

Fig. 4. The percentage composition of the ciliate volume on the different carbohydrate diets.

The total volume of the microbe mass varied from $3.5 \%$ of the rumen content on the sucrose diets to $5.2 \%$ on the $30 \%$ cellulose diet (Fig. 5). The values were significantly higher $(\mathrm{P}<0.05)$ on the two cellulose diets than on all the other diets, and significantly lower $(\mathrm{P}<0.05)$ on the sucrose diets than on all the others except the $15 \%$ starch diet.

The ciliates constituted a rather small proportion of the rumen content, between 0.5 and $1.2 \%$. One reason is that some large ciliate species, for instance Isotricha and Dasytricha, were completely lacking. Ciliate volumes of about this magnitude have found in cows (SCHUMACHER 1962), but the values in domestic ruminants have generally been higher (MOWRY and BECKER 1930, WARNER 1962, HARMEYER 1963).

The contribution of the bacteria to the total microbe volume was fairly high, the average for all the diets being 4.5 times as high as that of the ciliates. The ratio of bacteria to ciliate volumes was highest, 6.0 , on the $30 \%$ sucrose diet and lowest, 3,3 , on the $30 \%$ cellulose diet.

In earlier studies, the ciliate mass has been found to be roughly equal to that of the bacteria in domestic ruminants (AвоU AккаDA 1965) and 4.6 times as high in semidomestic reindeer (SYRJ $\ddot{L} L \ddot{A}$ et al. 1973). In other experiments (OXFORD 1964, WARNER 1965), the bacteria have been found to compose the largest part of the microbial mass, as in the present study.

\section{Effect of silage preservatives}

The values for the diet consisting of silage alone are the averages of $\mathbf{1 8}$ rumen samples and those for the diets containing carbohydrate supplements are the averages of $\mathbf{5 4}$ samples.

Only slight and non-significant differences $(P>0.05)$ were found in the total numbers of ciliates and bacteria between the silages prepared with different preservatives (Table 4, Fig. 6). The differences in the numbers of the various ciliate species were significant $(\mathrm{P}<0.05$ or $\mathrm{P}<0.01)$ in only a few cases.

The total numbers of both ciliates and bacteria tended to be higher on the Viher solution silage diets than on the other diets. The numbers of bacteria 
Fig. 5. The total microbe mass as a percentage of the rumen content in sheep on different carbohydrate diets $(\mathrm{O}=$ only silage, Suc $=$ sucrose, Sta $=$ starch, $\mathrm{Cel}=$ cellulose $)$.

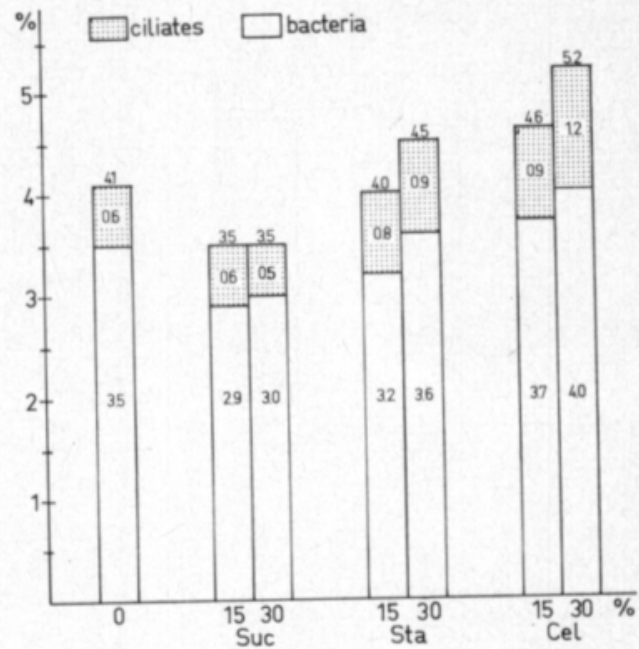

were higher on the formic acid silage diets than on the AIV I silage diets. The number of ciliates was higher on the AIV I silage diet than on the formic acid diet when only silage was given, but the situation was reversed with the diets containing the carbohydrate supplements.

Table 4. The mean number of ciliate $\left(n \times 10^{3}\right)$ and bacteria $\left(n \times 10^{9}\right)$ cells per ml rumen content in sheep on AIV I, formic acid and Viher solution silage diets.

\begin{tabular}{|c|c|c|c|c|c|c|}
\hline & \multicolumn{3}{|c|}{ Diets consisting only of silage } & \multicolumn{3}{|c|}{$\begin{array}{c}\text { Diets also containing } \\
\text { carbohydrate supplements }\end{array}$} \\
\hline & AIV I & $\begin{array}{l}\text { Formic } \\
\text { acid }\end{array}$ & $\begin{array}{l}\text { Viher } \\
\text { solution }\end{array}$ & AIV & $\begin{array}{l}\text { Formic } \\
\text { acid }\end{array}$ & $\begin{array}{l}\text { Viher } \\
\text { solution }\end{array}$ \\
\hline Total ciliates ... & 516.74 & 483.13 & 532.62 & 488.84 & 526.96 & 535.29 \\
\hline Charon ............................. & 288.10 & 251.53 & 266.72 & 248.15 & 250.29 & 266.63 \\
\hline Entodinium vorax ............. & $0.34^{\mathrm{a}}$ & $1.30^{\mathrm{b}}$ & $0.28^{\mathrm{a}}$ & 0.78 & 0.90 & 0.91 \\
\hline E. longinucleatum ............. & 3.00 & 4.08 & 3.40 & 3.29 & 4.56 & 4.50 \\
\hline E. triacum .................... & $2.84^{\mathrm{a}}$ & $4.11^{\mathrm{a}}$ & $24.34^{\mathrm{b}}$ & $1.46^{\mathrm{a}}$ & $2.08^{\mathrm{a}}$ & $11.38^{b}$ \\
\hline E. caudatum .................. & 2.50 & 1.64 & 2.63 & 7.44 & 6.21 & 5.46 \\
\hline E. loboso-spinosum .......... & 4.42 & 2.50 & 4.36 & 5.36 & 6.68 & 4.82 \\
\hline E. nanellum .................... & 27.71 & 31.20 & 29.19 & 30.30 & 36.28 & 32.57 \\
\hline E. dubardi ....................... & 160.10 & 161.82 & 176.90 & 166.84 & 190.06 & 178.62 \\
\hline Diplodinium dentatum ....... & 2.72 & 2.38 & 3.00 & 2.48 & 2.77 & 2.03 \\
\hline Eudiplodinium maggii ........ & 0.80 & 1.26 & 1.51 & 1.87 & 1.19 & 1.39 \\
\hline 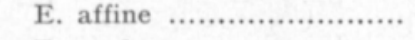 & 5.99 & 3.46 & 5.28 & $4.79^{\mathrm{a}}$ & $4.35^{\mathrm{a}}$ & $10.10^{\mathrm{b}}$ \\
\hline E. neglectum ................... & 3.67 & 5.47 & 1.76 & $1.88^{\mathrm{a}}$ & $4.77^{\mathrm{b}}$ & $1.14^{\mathrm{a}}$ \\
\hline $\begin{array}{l}\text { Polyplastron } \\
\text { multivesiculatum .............. }\end{array}$ & 2.38 & 1.88 & 1.64 & 3.36 & 3.68 & 3.08 \\
\hline Enopoplastron triloricatum & 12.17 & 10.50 & 11.61 & 10.84 & 13.14 & 12.66 \\
\hline Bacteria ............................. & 35.02 & 35.14 & 35.57 & 33.68 & 34.45 & 35.02 \\
\hline
\end{tabular}

Statistical analysis performed separately for diets consisting only of silage and for diets also containing carbohydrate supplements. Meaning of index letters same as in Table 2 . 


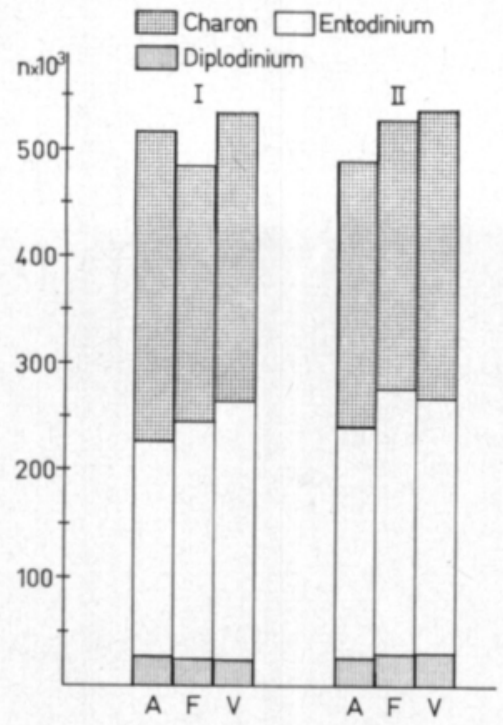

Fig. 6. The mean number of ciliate cells $\left(\mathrm{n} \times 10^{3}\right)$ per $\mathrm{ml}$ rumen content in sheep fed on AIV I (A), formic acid (F) and Viher solution (V) silage, alone (I) or with carbohydrate supplements (II).

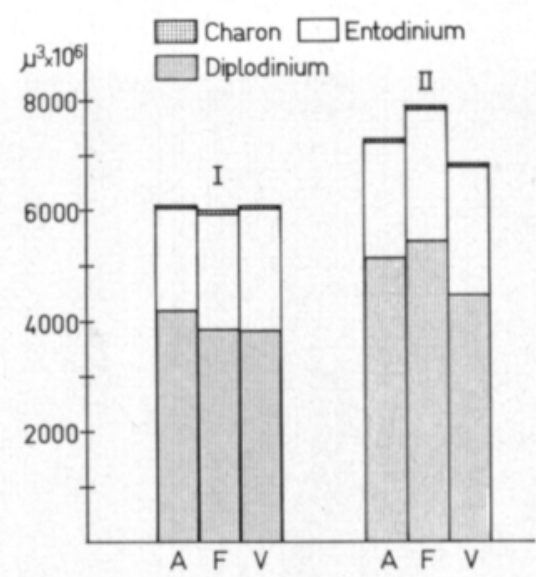

Fig. 7. The mean volume of ciliates $\left(\mu^{3} \times 10^{6}\right)$ per $\mathrm{ml}$ rumen content in sheep fed on AIV I (A), formic acid (F) and Viher solution (V) silage, alone (I) or with carbohydrate supplements (II).

The volumes of the different ciliates were about the same on the different silage diets, especially on the pure silage $\operatorname{diet}(\mathrm{P}>0.05$, Fig. 7). The total volumes of ciliates on the pure AIV I, formic acid and Viher solution silages were 6094,5975 and $6078 \mu^{3} \times 10^{3}$ per ml rumen content, respectively. The corresponding values on the diets containing carbohydrate supplements were 7284, 7881 and 6818 . The genus Entodinium constituted the highest proportion of the ciliate volume on the Viher solution silage diets and a higher proportion on the formic acid silage diets than on the AIV I silage diets. The contribution of the genus Diplodium decreased in the opposition direction: AIV I $>$ formic

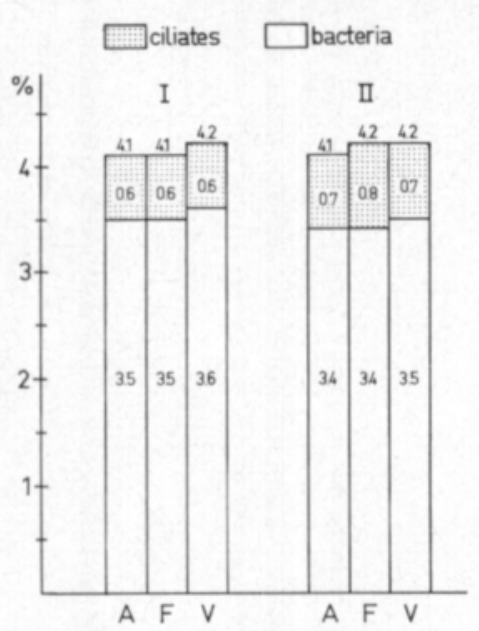
acid $>$ Viher solution. The contribution of Charon was about the same on all the silage diets. The differences in the total microbe mass between the different silage diets were also non-significant $(\mathrm{P}>0.05$, Fig. 8).

Fig. 8. The total microbe mass as a percentage of the rumen content in sheep fed on AIV I (A), formic acid (F) and Viher solution (V) silage, alone (I) or with carbohydrate supplements (II). 


\section{General considerations}

The investigation reported in this paper concern the effect of sucrose, starch and cellulose supplements, at levels of $2 \frac{1}{2} \mathrm{~g}$ and $5 \mathrm{~g} / \mathrm{kg}$ live weight per day, on the composition and volume of the rumen microbiota of sheep fed on grass silage prepared with different preservatives.

The carbohydrate source affected the rumen microbiota more than the level at which it was used. The total number of ciliates was highest in the animals receiving sucrose with the silage, lower in those on starch diets and lowest in those given cellulose. On the pure silage diet, the ciliate number was between those for the starch and cellulose diets. The total number of bacteria was highest on the cellulose diets, lower on the pure silage and starch diets and lowest on the sucrose diets. These variations in the numbers of ciliate and bacteria cells can mainly be attributed to differences in the solubility of the carbohydrates.

The sucrose supplements increased the numbers of small ciliates especially and the cellulose supplements raised those of the bigger ciliates. The total volume of the ciliate fauna was thus highest in the animals on cellulose diets, lower in those on starch diets and lowest in those on sucrose diets. The contribution of the total microbe mass to the rumen content decreased in the same direction: cellulose $>$ starch $>$ sucrose.

In the earlier study (SYRJÄL $\ddot{A}$ 1972) in which the same rumen samples were used as in this experiment, the average ammonia content of the rumen fluid was lower on the sucrose diets than on the starch and cellulose diets with the same levels of carbohydrate supplements. When this finding is considered together with present results, it appears that the decrease of the rumen ammonia content depends more on the numbers of the ciliate cells than on the volume of the ciliate fauna. Perhaps the bigger ciliates contain relatively more polysaccharides than the smaller ciliates, so that the protein content is relatively higher in a ciliate mass formed from smaller cells than in one formed from larger cells.

The average amounts of total volatile fatty acids behaved in the same way in relation to the different carbohydrate diets as the volume of the ciliate fauna, decreasing from cellulose to starch to sucrose. However, these results cannot be considered to reflect the fermentation activity of the ciliates alone or its dependence on, for instance, the volume of the ciliates, because the amount of bacteria was not the same on the different diets. The bacteria counts were highest on the cellulose diets, lower on the starch diets and lowest on the sucrose diets. The importance of the bacteria flora in this experiment is evident from its high contribution to the total rumen microbe mass compared with that of the ciliate fauna. It constituted $77-86 \%$ of the mass on the different diets, the percentage being highest on the sucrose diet and lowest on the cellulose one.

The ciliates and bacteria were counted on samples taken only once a day, in the morning before feeding. In contrast, the $\mathrm{pH}$, ammonia and VFA content were determined on samples taken three times a day (SYRJÄL $\ddot{A}$ 1972). This investigation of the microbiota thus describes only the situation at the begin- 
ning of feeding and does not give any information on qualitative and quantitative changes occurring during the day (PURSER and MoIr 1959, WArner 1962). Consequently, the results cannot be used as a measure of the protein utilization of the host. They do, however, permit a comparison of the effects of the different diets on the rumen microbiota.

The other indices of the utilization of the nitrogenous compounds of silage, such as the nitrogen balance and the biological value of protein, were also somewhat better on the sucrose diets than on the corresponding starch and cellulose diets. In contrast, the apparent digestibility coefficients were generally higher on the cellulose diets than on the starch or especially on the sucrose diets. It must, however, be remembered that the metabolic nitrogen substances of the faeces are not separated when apparent digestibility is determined and that soluble carbohydrates have been found to increase its proportion in the faeces (Hamilton 1942, Fontenot et al. 1955, Paloheimo et al. 1968, SYRJÄLÄ 1971).

The different silage preservatives were found to have little effect on the composition and volume of the ruminal microbiota. Similarly, little variation was found in the digestibility values of the silages, except that of crude protein, which was lower for the Viher solution silage than the other silages (SYRJÄLÄ 1972). Some significant differences were found in the rumen fermentation products between the different silage diets. The ammonia concentration in the rumen fluid was, on average, lower on the Viher solution silage diets than on the other silage diets, which was attributed to the formaldehyde contained by the Viher solution (SYRJÄLÄ 1972). But according to the results of the present experiment, the formaldehyde did not have a notable effect on the rumen microbiota.

\section{REFERENCES}

Aвe, M., Shibui, H., Iriki, T. \& Kumeno, F. 1973. Relation between diet and protozoal population in the rumen. Br. J. Nutr. 29: 195.

Aвou Aкkada, A. R. 1965. The metabolism of ciliate protozoa in relation to rumen function. Physiology of digestion in the ruminant, 335-345. Ed. Dougherty, R. W., Washington.

- - - Hobson, P. N. \& Howard, B. H. 1959. Carbohydrate fermentation by rumen oligotrich protozoa of the genus Entodinium. Biochem. J. 73, 44 p.

Barnett, A. J. G. 1954. Silage fermentation. 208 p. London.

- - \& REID, R. L. 1961. Reactions in the rumen. 252 p. London.

Dogrel, V. A. 1927. Monographie der Familie Ophryscolecidae. Arch. Protistenk. 59: 1-288.

EAdie, J. M. \& Hobson, P. N. 1962. Effect of the presence or absence of rumen ciliate protozoa on the total rumen bacterial counts in lambs. Nature 193: 503-505.

Fontenot, J. P., Gallup, W. D. \& Nelson, A. B. 1955. Effect of added carbohydrates on the utilization by steers of nitrogen in wintering rations. J. Anim. Sci. 14: 807-817.

Hamirton, T. S. 1942. The effect of added glucose upon the digestibility of protein and fiber in rations for sheep. J. Nutr. 23:101-110.

HARMeyer, J. 1963. Isolierung, Differenzierung und analytische Ergebnisse der Protozoenfauna der Ziege. Thesis 44 p. Hannover. 
Hungate, R. E. 1955. The ciliates of the rumen. Biochemistry and Physiology of the Protozoa 2: 159-179. Ed. Hutner and Lwoff. New York.

,- 1966 . The rumen and its microbes. 533 p. New York.

- - , Dougherty, R. W., Bryant, M. P. \& Cello, R. M. 1952. Microbiological and physiological changes associated with acute indigestion in sheep. Cornell Vet. 42: 423 -449 .

KellogG, D. W. 1969. Influence of sucrose on rumen fermentation pattern and milk fat content of cows fed a high-grain ration. J. Dairy Sci. 52:1601-1604.

Kofoid, C. A. \& MacLennan, R. F. 1930. Ciliates from Bos indicus Linn., I. The Genus Entodinium Stein. Univ. Calif. Publ. Zool. 33: 471-544.

-, 1932. Ciliates from Bos indicus Linn., II. A revision of Diplodinium Schuberg. Univ. Calif. Publ. Zool. 37: 53-152.

- -1933 . Ciliates from Bos indicus Linn., III. Epidinium Crawley, Epiplastron Gen. nov. and Ophryoscolex Stein. Univ. Calif. Publ. Zool. 39:1-34.

Komkris, T., Stanley, R. W. \& Morita, K. 1965. Effects of feed containing molasses fed separately and together with roughage on digestibility of rations, volatile fatty acids produced in the rumen, milk production, and milk constituents. J. Dairy Sci. 48: $714-719$.

KRoGH, N. 1959. Studies on alterations in the rumen fluid of sheep, especially concerning the microbial composition, when readily available carbohydrates are added to the food. I. Sucrose. Acta Vet. Scand. 1: 74-97.

Mitchell, H. H. \& Hamilton, T. S. 1940. The utilization by calves of energy in rations containing different percentages of protein and in glucose supplement. J. Agric. Res. 61: $847-864$.

Morr, R. J. \& Willinms, V. J. 1950. Ruminal flora studies in the sheep. II. The effect of the level of nitrogen intake upon the total number of free microorganisms in the rumen. Austral. J. Scient. Res. 3 (B): 381-392.

Mowry, H. A. \& Becker, E. R. 1930. Experiments on the biology of infusoria inhabiting the rumen of goats. Iowa State College J. Sci. 5:35-60.

Norrot-TrmotheE, C. 1960. Etude d'uni famille de ciliés: les „Ophryoscolecidaen. Structures et ultrastructures. Ph. D. These, Univ. Paris, Masson et Cie, Paris.

OXford, A. E. 1955. The bacteriology and protozoology of ruminant digestion. J. Sci. Fd. Agric. 6: 413-418.

-1 - 1964. A guide to rumen microbiology. Bulletin 160, 103 p. New Zealand.

Palohermo, L., Syrjälä, L. \& Varnio, K. A. 1968. Studies on the faeces. Maat. tiet. aikakauskirja 40: $237-246$.

Purser, D. B. \& Morr, R. J. 1959. Ruminal flora studies in the sheep. IX. The effect of $\mathrm{pH}$ on the ciliate population of the rumen in vivo. Austral. J. Agric. Res. 10: 555564.

Quinn, L. Y., Burroughs, W. \& Christiansen, W. C. 1962. Continuous culture of ruminal microorganisms in chemically defined medium, II. Appl. Microbiol. 10: 583-592.

Salo, M.-L., ORAкоsкI, H. \& Suомı, K. 1973 a. Sokeri- ja tärkkelyslisäyksen vaikutus säilörehun sulavuuteen ja typen pidättymiseen pässeillä. J .Scient. Agric. Soc. Finl. 45: $512-518$.

— - , Immonen, M. \& LUomajärvi, U. 1973 b. Rehuyhdistelmän sokeripitoisuuden vaikutus lehmien maidontuotantoon ja veriarvoihin. J. Scient. Agric. Soc. Finl. 45: $519-527$.

Schumacher, E. 1962. Ǔber die Wirkung einiger Sulfonamide und Antibiotika auf die Infusorien und die Gärgasbildungen im Panseninhalt des Rindes. Schweiz. Arch. Tierheilk. 104: 491-518.

Steele, R. G. D. \& Torrie, J. H. 1960. Principles and procedures of statistics. 481 p. New York.

Surron, J. D. 1968. The fermentation of soluble carbohydrates in rumen contents of cows fed diets containing a large proportion of hay. Brit. J. Nutr. 22: 689-712.

SyrJäLÄ, L. 1971. Effects of different sucrose levels on digestiblity and mastication of hay and yield and composition of milk in dairy cow. J. Scient. Agric. Soc. Finl. 43: 94102. 
--1972 . Effect of different sucrose, starch and cellulose supplements on the utilization of grass silages by ruminants. Ann. Agric. Fenn. 11: 199-276.

,- 1975 . Live-weight gain, feed intake and wool growth of lambs on different grass silages and sucrose and starch supplements. Ann. Agric. Fenn. 14: 338-348.

- -, Kossil.A, V. \& SipILÄ, H. 1973. A study of nutritional status of Finnish reindeer (Rangifer Tarandus L.) in different months. I. Composition and volume of the rumen microbiota. J. Scient. Agric. Soc. Finl. 45: 534-541.

VirTANEN, A. I. 1967. The production of milk on protein-free rations. Urea as a protein supplement 185-212, ed. Briggs, London.

WARNER, A. C. I. 1962. Some factors influencing the rumen microbial population. J. Gen. Microbiol. 28: 129-146.

- -1965 . Factors influencing number and kinds of micro-organisms in the rumen. Physiology of digestion in the ruminant, 346-359. Ed. Dougherty, Washington.

Westerling, B. 1970 a. Rumen ciliate fauna of semi-domestic reindeer (Rangifer Tarandus L.) in Finland: Composition, volume and some seasonal variations. Acta Zoolog. Fenn. 127: $1-76$.

- -1970 b. The effect of some factors on the cell volume of rumen ciliates. Acta Vet. Scand. 11: $565-570$.

MS received September 4, 1975. 


\title{
Sokeri-, tärkkelys- ja selluloosalisäysten vaikutus erilaisilla säilörehuilla ruokittujen lampaiden pötsimikrobiston määrään ja koostumukseen
}

\author{
LiIsa Syrjälä ${ }^{1}$ ), Hannu Saloniemi ${ }^{2}$ ) ja Leena LaAlahti ${ }^{1}$ ) \\ 1) Helsingin yliopiston kotieläintieteen laitos \\ $\left.{ }^{2}\right)$ Eläinlääketieteellisen korkeakoulun kotieläinhygienian laitos, Helsinki
}

Tutkimuksen tarkoituksena oli selvittää säilörehuannokseen lisättyjen eri suurien sokeri-, tärkkelys- ja selluloosamäärien sekä erilaisten sảilöntäaineiden vaikutusta märehtijäin pōtsin mikrobiston määrään ja laatuun.

Koe suoritettiin latinalaisten neliöiden mukaan yhdeksällä täysikasvuisella pässillä, joille oli tehty pōtsifisteli. Alkueläinten ja bakteerien mikroskooppinen laskeminen tehtiin pötsinäytteistä, jotka oli otettu jokaisen koejakson lopulla kahtena päivänä aamulla ennen ruokintaa.

Hiilihydraattilisäyksillă korvattiin $15 \%$ ja $30 \%$ päivittäisen rehuannoksen kuiva-aineesta, joka oli keskimäärin $928 \mathrm{~g}$. Hiilihydraattilisäykset olivat tällöin $21 / 2$ ja $5 \mathrm{~g}$ elopainokiloa kohti päivässä. Kokeessa käytetyt säilörehut oli valmistettu kolmella eri säilöntäaineella: AIV I:llä, muurahaishapolla ja Viherliuoksella.

Tutkimuksessa havaittiin, että hiilihydraatin laadulla oli suurempi vaikutus pötsimikrobistoon kuin sen määrällä. Alkueläinten lukumäärä oli suurin silloin, kun eläimet saivat såilörehuruokinnan yhteydessä sokeria, seuraavaksi suurin tärkkelysdieeteillä ja alhaisin selluloosadieeteillä. Pelkällä säilörehudieetillä jäi alkueläinten lukumäärä tärkkelys- ja selluloosadieeteillä saatujen määrien väliin. Bakteerien lukumäärä oli suurin selluloosadieeteillä, seuraaviksi suurin pelkällä säilörehulla ja tärkkelysdieeteillä sekä alhaisin sokeridieeteillä.

Sokeridieeteillä alkueläimistō koostui muihin dieetteihin verrattuna suhteellisesti suuremmassa määrin kooltaan pienistä alkueläimistä, kun taas selluloosadieeteillä tavattiin suhteellisesti enemmän suurikokoisia alkueläimiä. Tästä oli seurauksena, että alkueläimistön kokonaistilavuus muodostui selluloosadieeteillä suuremmaksi kuin sokeridieeteillä tärkkelysdieetin jäădessä näiden väliin.

Koko mikrobimassan prosenttinen osuus pötsin sisällön tilavuudesta oli eri dieeteillä seuraava: pelkkää säilörehua $4.1,15 \%$ sokeria $3.5,30 \%$ sokeria $3.5,15 \%$ tärkkelystä $4.0,30 \%$ tärkkelystä $4.5,15 \%$ selluloosaa 4.6 ja $30 \%$ selluloosaa 5.2. Bakteerien osuus koko mikrobimassan tilavuudesta oli suhteellisen korkea, $77-86 \%$ eri dieeteillä, suurimman osuuden ollessa sokeridieeteillä ja pienimmän selluloosadieeteillä.

Eri säilöntäaineilla valmistetuilla rehuilla ruokittaessa ei havaittu mainittavia eroja pötsin mikrobiston määrässä ja laadussa. 